\title{
Short term outcome of radial head arthroplasty in Mason type 3 and 4 fractures
}

\section{Mudasir Rashid Ganai, Shahid Shabir Khan, Inayat Rahim*, Saheel Maajid, Tahir Ahmad Dar}

Department of Orthopaedics, SKIMS MC and H, Srinagar, India

Received: 25 April 2021

Accepted: 29 May 2021

*Correspondence:

Dr. Inayat Rahim,

E-mail: inayatrahim82@gmail.com

Copyright: ( $)$ the author(s), publisher and licensee Medip Academy. This is an open-access article distributed under the terms of the Creative Commons Attribution Non-Commercial License, which permits unrestricted non-commercial use, distribution, and reproduction in any medium, provided the original work is properly cited.

\begin{abstract}
Background: Radial head arthroplasty provides a suitable treatment in Mason type 3 and 43 fractures. Arthroplasty produces consistent results with a shorter learning curve than ORIF and prevents the late complications associated with radial head excision.

Methods: After seeking approval from local institutional ethical committee 30 patients with Mason type 3 and 4 radial head fractures were admitted from outpatient department (OPD) of SKIMS MC and Hospital Bemina, Srinagar. The study was conducted from February 2019 to June 2020 in department of Orthopaedics SKIMS MC and Hospital Bemina, Srinagar. 30 patients with mean age of 25 years comprising of 9 females and 21 males underwent radial head arthroplasty and were followed up to a minimum of 1 year post-operatively.

Results: Outcome was evaluated by assessing elbow functional performance using Mayo elbow performance (MEPI). No revisions were performed during the study. Two patients had implant backout and 6 patients had elbow stiffness.

Conclusions: Radial head arthroplasty can be used successfully with most of excellent results for treatment of comminuted radial head fracture (Mason type III and IV radial head fractures). Over all radial head arthroplasty is a demanding option in type 3 and type 4 fractures which are not amenable to reconstruction.
\end{abstract}

Keywords: Mason classification, Radial head arthroplasty, Mayo elbow performance

\section{INTRODUCTION}

Fractures of the radial head first were described in 1905 and were generally treated by immobilization. ${ }^{1,2}$ Radial head and neck fractures are estimated to account for $1.7 \%$ to $5.4 \%$ of all fractures seen today.

Depending on the fracture pattern and associated softtissue injury several types of treatment exist for fractured radial heads. Radial head arthroplasty provides a suitable treatment in Mason type 3 and 43 fractures. ${ }^{3}$ Arthroplasty produces consistent results with a shorter learning curve than ORIF and prevents the late complications associated with radial head excision. ${ }^{4}$

\section{METHODS}

This prospective interventional study was conducted in SKIMS medical college hospital, Bemina Srinagar from February 2019 to June 2020. 30 patients meeting the inclusion criteria were admitted to SKIMS MC hospital. All the patients were operated after pre-operative workup by the same surgeon via the same approach (Kocher approach) after getting approval from institutional ethical committee. The implant used was same in all patients. A modular radial head implant system was used. Postoperative management included intra-venous antibiotics. Patients with stable elbow were started with active flexion and extension exercises throughout a full arc of motion 3 days after surgery. Radiographs were taken in 
immediate postoperative period, 6 month and 1 year follow up. 5 Follow up was done at 2 weeks, 3 months, 6 months and final follow up at 1 year. Elbow functional performance was assessed by Mayo Elbow performance (MEPI). 6.7

\section{Inclusion criteria}

Age- 20 years or more; all sexes; Morrey modified Mason's type-III and type-IV; closed fractures, patients who can attend OPD for atleast 1 year.

\section{Exclusion criteria}

Age less than 20 years; Morrey modified Mason's type-I and type-II; open fractures; pathological fractures; associated neurovascular injury; presence of any infection.

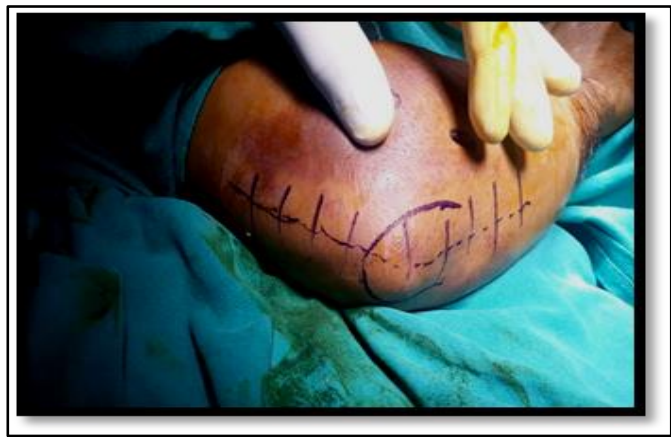

Figure 1: Surgical landmarks.

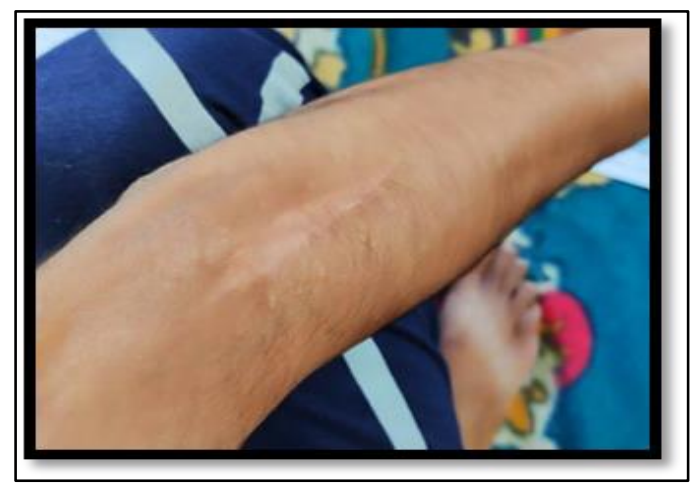

Figure 2: Surgical scar.

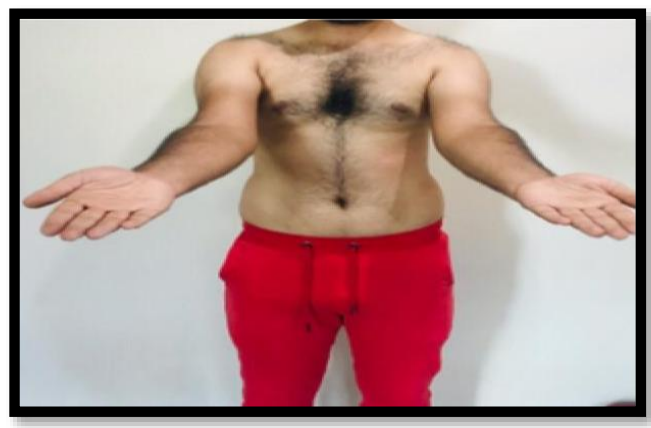

Figure 3: Elbow extension.

\section{Statistical analysis}

Data was entered on microsoft excel software and analysis was done with Statistical package for social sciences (SPSS) version 20.0 software.

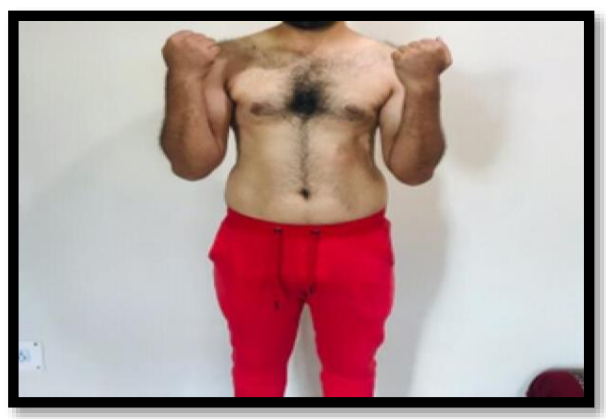

Figure 4: Elbow flexion.

\section{RESULTS}

The study patients were in the age group of 20 to 30 years with mean age of 25 years. 9 females and 21 males were studied. 13 patients had left elbow involvement and 17 patients had right elbow involvement. In our study, $80 \%$ of patients presented with type III fracture while the rest $20 \%$ with Mason type IV fracture. In our study, radial head fractures were associated with LCL injury in $20 \%$ patients, MCL injury in $7 \%$ cases and elbow dislocation in $30 \%$ of patients.

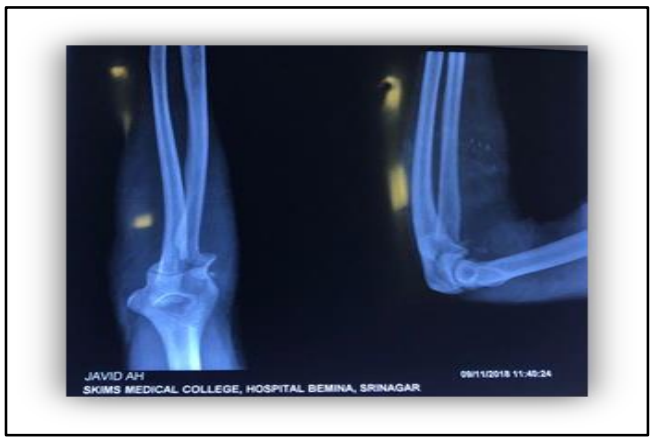

Figure 5: Pre-operating radiograph.

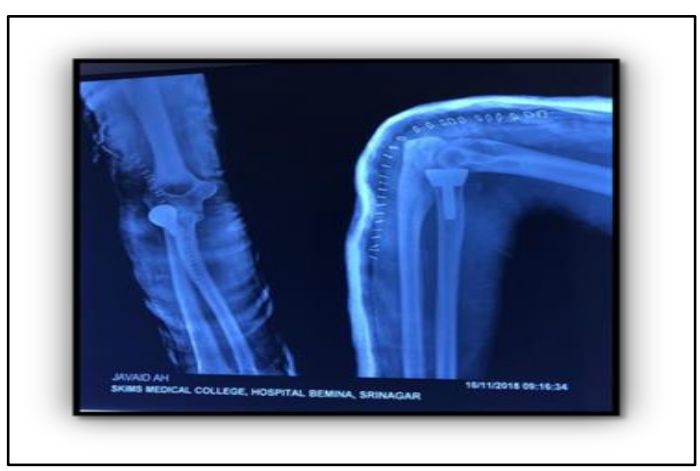

Figure 6: Post-operative radiograph. 
Out of 30 patients, $73 \%$ patients at the end of follow up showed excellent outcomes. $20 \%$ showed good results while the rest $7 \%$ showed poor functional outcomes.

In our study, 6 patients had elbow stiffness and 2 patients had implant backout.

Table 1: Results.

\begin{tabular}{|ll|}
\hline Parameters & Results \\
\hline Mean age & 25 years \\
\hline Gender ratio & $9: 21$ (females : males) \\
\hline Side involvement & $17: 13$ (right : left) \\
\hline
\end{tabular}

Table 2: Complications.

\begin{tabular}{|lll|}
\hline Complication & $\begin{array}{l}\text { No. of } \\
\text { patients }\end{array}$ & Percentage \\
\hline Implant backout & 2 & 7 \\
\hline Elbow stiffness & 6 & 20 \\
\hline Not applicable & 22 & 73 \\
\hline Total & 30 & 100 \\
\hline
\end{tabular}

Table 3: Associated injuries.

\begin{tabular}{|ll|}
\hline Associated injuries & No. of patients \\
\hline LCL Injury & 6 \\
\hline MCL Injury & 2 \\
\hline Elbow Dislocation & 9 \\
\hline No associated Injury & 13 \\
\hline
\end{tabular}

Table 4: Mayo elbow performance.

\begin{tabular}{|lll|}
\hline Results & $\begin{array}{l}\text { No. of } \\
\text { patients }\end{array}$ & Percentage \\
\hline Excellent & 22 & 73 \\
\hline Good & 6 & 20 \\
\hline Fair & 0 & 0 \\
\hline Poor & 2 & 7 \\
\hline Total & 30 & 100 \\
\hline
\end{tabular}

\section{DISCUSSION}

In our study $60 \%$ patients were in the $20-30$ age group. Male predominance was found in our study. $67 \%$ patients were males and the rest were females. Majority of patients $(65 \%)$ had history of accidental fall. Right side involved in $70 \%$ of patients and left side involved in $30 \%$ of patients. The results of the study were compared with the studies of Morrey et al 1985, Judet et al 2005 and Choudhary et al 2019..$^{8-11}$

In our study, type III Mason fracture was found in $80 \%$ of patients while $20 \%$ had type IV Mason radial head fracture. The results were compared with the studies of Ikeda et al 2003, Dotzis et al 2006 and Businger et al 2010. ${ }^{12-14}$
At the end of this study, $73 \%$ patients at the end of 6 month follow up showed excellent outcomes. $20 \%$ showed good results while the rest $7 \%$ showed poor functional outcomes. These results were comparable with few other studies conducted by Goldberg et al 1986, Fuchs et al 1999, Iftimie et al 2011 and Yalcinkaya et al 2013. ${ }^{15-18}$

Prolonged immobilization of elbow is attributable to elbow stiffness as mentioned by King et al and early mobilization had been advised to prevent this complication. ${ }^{19-21}$ Likewise we started early mobilization of the patients from POD 7 onwards, 15 patients had stiffness. None of the studied patients had any evidence of heterotopic ossification at final follow-up.

\section{CONCLUSION}

The prosthetic replacement of non reconstructable radial head fracture provides the platform for effective longterm function of the affected limb. Radial head arthroplasty can be used successfully with most of excellent results for treatment of Comminuted radial head fracture (The Modified Mason classification type III and IV radial head fractures). Over all radial head arthroplasty is a demanding option in type 3 and type 4 fractures which are not amenable to reconstruction.

Funding: No funding sources

Conflict of interest: None declared

Ethical approval: The study was approved by the institutional ethics committee

\section{REFERENCES}

1. Furry KL, Clinkscales CM. Comminuted fractures of the radial head: arthroplasty versus internal fixation. Clin Orth Rel Res. 1998;353:40-52.

2. Morrey BF. Radial head fracture. In: The elbow and its disorders. Morrey BF, ed. 3rd ed. Philadelphia: WB Saunders. 2000;341-64.

3. Mason ML. Some observations on fracture of the head of the radius with a review of one hundred cases. Br J Surg. 1954;42:123-32.

4. Herbertsson P, Josefsson PO, Hasserius R, Besjakov J, Nyqvist F, Karlsson MK. Fractures of the radial head and neck treated with radial head excision. J Bone Joint Surg. 2004;86A:1925-30.

5. Harrington IJ, Sekyi-Otu A, Barrington TW, Evans DC, Tuli V. The functional outcome with metallic radial head implants in the treatment of unstable elbow fractures: A long-term review. J Trauma. 2001;50(1):46-52.

6. Smith MV, Calfee RP, Baumgarten KM, Brophy RH, Wright RW. Upper extremity-specific measures of disability and outcomes in orthopaedic surgery. J Bone Joint Surg Am. 2012;94(3):277-85.

7. Broberg MA, Morrey BF. Results of delayed excision of the radial head after fracture. J Bone Joint Surg Am. 1986;68(5):669-74. 
8. Morrey BF, An KN. Articular and ligamentous contribution to the stability of the elbow joint. J Sports Med. 1983;11:315-9.

9. Morrey BF, Askew LJ, Chao EY. A biomechanical study of normal functional elbow motion. J Bone Joint Surg Am. 1981;63(6):872-7.

10. Bain GI, Ashwood N, Baird R, Unni R. Management of Mason type-III radial head fractures with a titanium prosthesis, ligament repair, and early mobilization. Surgical technique. J Bone Joint Surg Am. 2005;87(1):136.

11. Choudhary BM. Is radial head resection a menace for the clinical outcomes of the elbow for communited radial head fractures? Int J TRes Orthop. 2019;1:706.

12. Ikeda M, Yamashina $\mathrm{Y}$, Kamimoto $\mathrm{M}$. Open reduction and internal fixation of comminuted fractures of the radial head using lowprofile miniplates. J Bone Joint Surg Br. 85:1040-4.

13. Dotzis A, Cochu G, Mabit C. Comminuted fractures of the radial head treated by the Judet floating radial head prosthesis. J Bone Joint Surg Br. 2006;88:7604.

14. Businger A, Ruedi TP, Sommer C. On-table reconstruction of comminuted fractures of the radial head. Injury. 2010;41:583-8.

15. Goldberg I, Peylan J, Yosipovitch Z. Late results of excision of the radial head for an isolated closed fracture. J Bone Joint Surg Am. 1986;68:675-9.
16. Fuchs S, Chylarecki C. Do functional deficits result from radial head resection? J Shoulder Elbow Surg. 1999;8:247-51.

17. Iftimie PP, Garcia CJ, Forcada GLI, Pedrouzo GJE, Gomà GJ. Resection arthroplasty for radial head fractures: long-term follow-up. J Shoulder Elbow Surg. 2011;20:45-50.

18. Yalcinkaya M, Bagatur AE, Erdogan S, Zorer G. Resection arthroplasty for mason type iii radial head fractures yield good clinical but poor radiological results in the long-term. J Orthop. 2013;36(11):135864.

19. King GJW, Faber KJ. Post Traumatic Elbow Stiffness. Orthop Clin N Am. 2000;31:129-14.

20. Paschos NK, Mitsionis GI, Vasiliadis HS, Georgoulis AD. Comparison of Early Mobilization Proto-cols in Radial Head Fractures. J Orthop Trauma. 2013;27:134-9.

21. Harding P, Rasekaba T, Smirneos L, Holland AE. Early Mobilisation for Elbow Fractures in Adults. In: The Cochrane Collaboration and P. Harding, Eds., Cochrane Database of Systematic Reviews. Chichester: John Wiley \& Sons, Ltd. 2011.

Cite this article as: Ganai MR, Khan SS, Rahim I, Maajid S, Dar TA. Short term outcome of radial head arthroplasty in Mason type 3 and 4 fractures. Int J Res Orthop 2021;7:830-3. 